\section{Prophets and Emperops}

Human and Divine Authority from Augustus to Theodosius DAVID POTTER

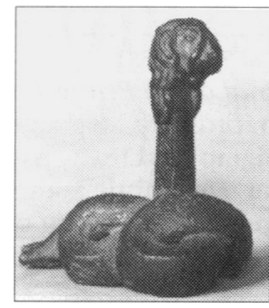

In Prophets and Emperors, David Potter shows us how prophecy worked, how it could empower, and how the diverse inhabitants of the Roman Empire used it to make sense of their world. The various systems of prophecyincluding sacred books, oracles, astrological readings, interpretation of dreams, the sayings of holy men and women-come into sharp relief. Potter explores the use of prophecy as a means of historical analysis and political communication, and he describes it in the context of the ancient city.

Revealing Antiquity, $7 \$ 45.00$ cloth

\section{The Galilee in Late Antiquity EDITED BY LEE I. LEVINE}

Galilee-the center of Jewish life in Palestine after the destruction of Jerusalem in 70 c.e., as well as a region of prime importance in early Christian history-is studied here by a wide spectrum of experts: historians and archaeologists, scholars of New Testament and Rabbinic literature, and students of social and cultural life in late antiquity. These twenty essays examine such issues as the first Christians, social and economic conditions, Roman rule and military presence, rabbis and Jewish law, and the archaeological remains of ancient synagogues The Jewish Theological Seminary of America 23 illus. \$17.95 paper

\section{Idolatry}

\section{MOSHE HALBERTALAND AVISHAI MARGALIT}

Translated by Naomi Goldblum

"A remarkably hard-nosed and often profound inquiry into the way Judaism in particular has constructed its concept of false or deviant worship... The authors' discussion consistently illuminates familiar texts and ideas with fresh questions and insights drawn from a variety of contemporary philosophical traditions."

-Martin Jaffe, Religious Studies Review $\$ 17.95$ paper

\section{Alienated Minopity}

The Jews of Medieval Latin Europe

\section{KENNETH STOW}

"What has heretofore been lacking both to students of medieval Jewish history and to general historians is a manageable, yet in-depth, analysis in English of the medieval Jewish experience. Stow provides such a study."

- Steven Bowman, Religious Studies Review $\$ 19.95$ paper

\section{Hasidic People}

\section{A Place in the New World} \section{JEROME R. MINTZ}

"By letting [his] subject speak for itself, Mintz [allows his] readers to encounter religious belief in all its unwieldy complexity... [His] work reveals a degree of immersion in his subject that few, if any, outsiders have ever achieved." --Alan Edeistein, Moment

$\$ 16.95$ paper

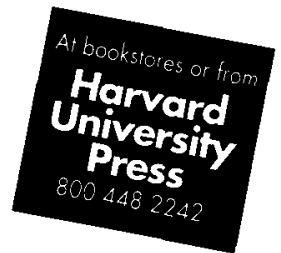



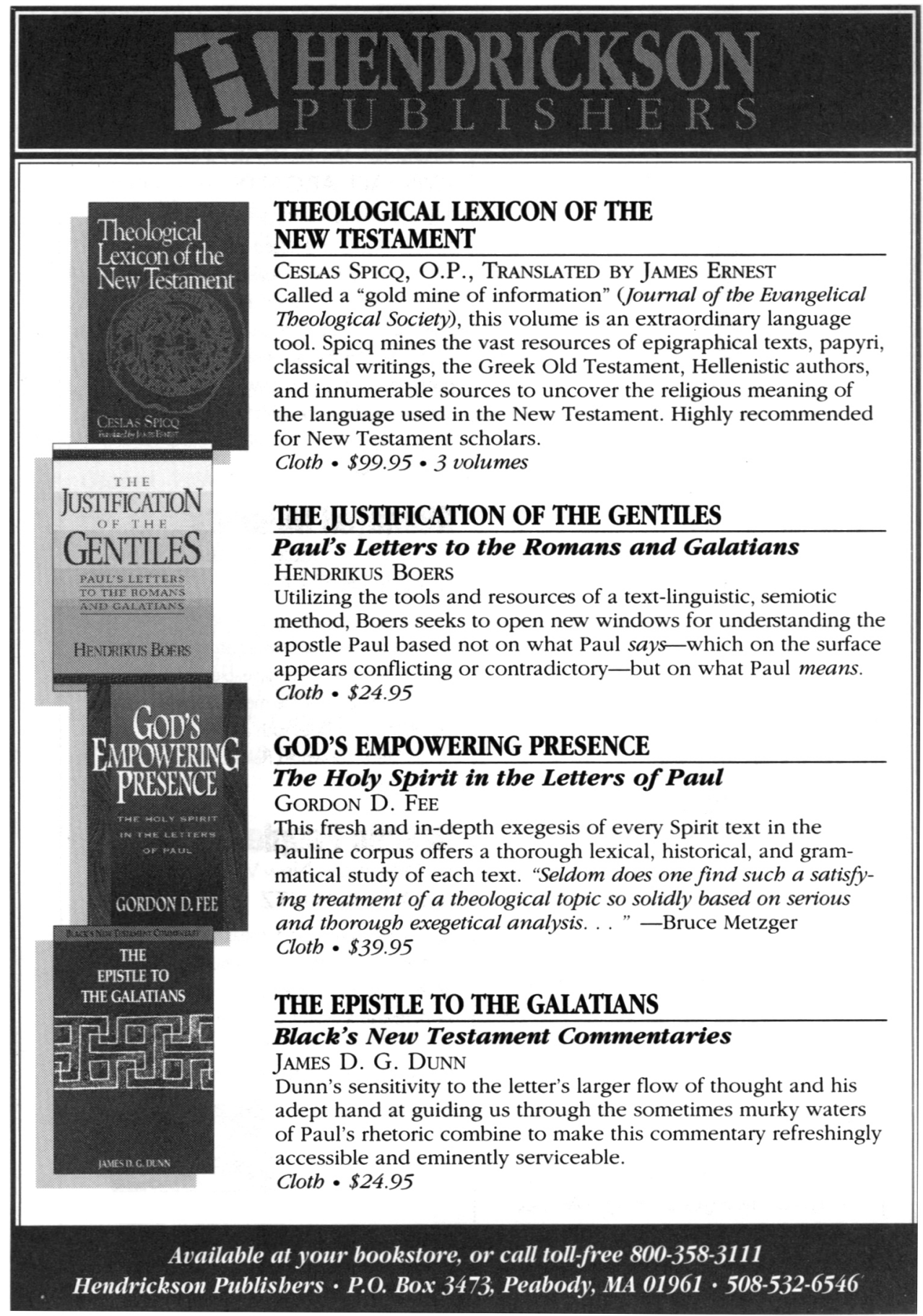


\section{THE EARLY CHURCH FATHERS}

Alexander Roberts, James Donaldson, Philip. SchafF, AND HENRY WACE, EDITORS

A classic resource for the scholar, student, or minister, the thirty-eight volume Early Church Fathers, including the Ante-Nicene Fathers, Nicene and Post Nicene Fathers, First and Second Series, is now available

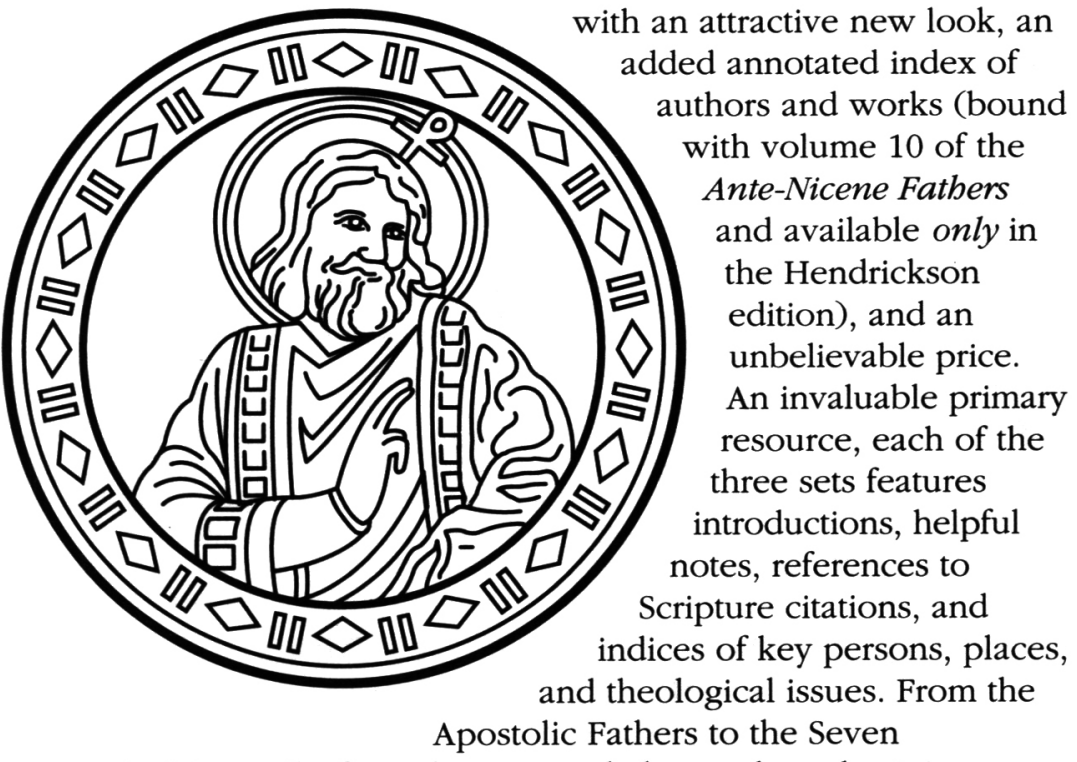

Ecumenical Councils, from the apocryphal gospels to the Arian controversy, this work is one of the most complete collections existing today of the writing in the Christian church's first 800 years.

Cloth $\bullet \$ 1,100.00 \cdot 38$ volumes 

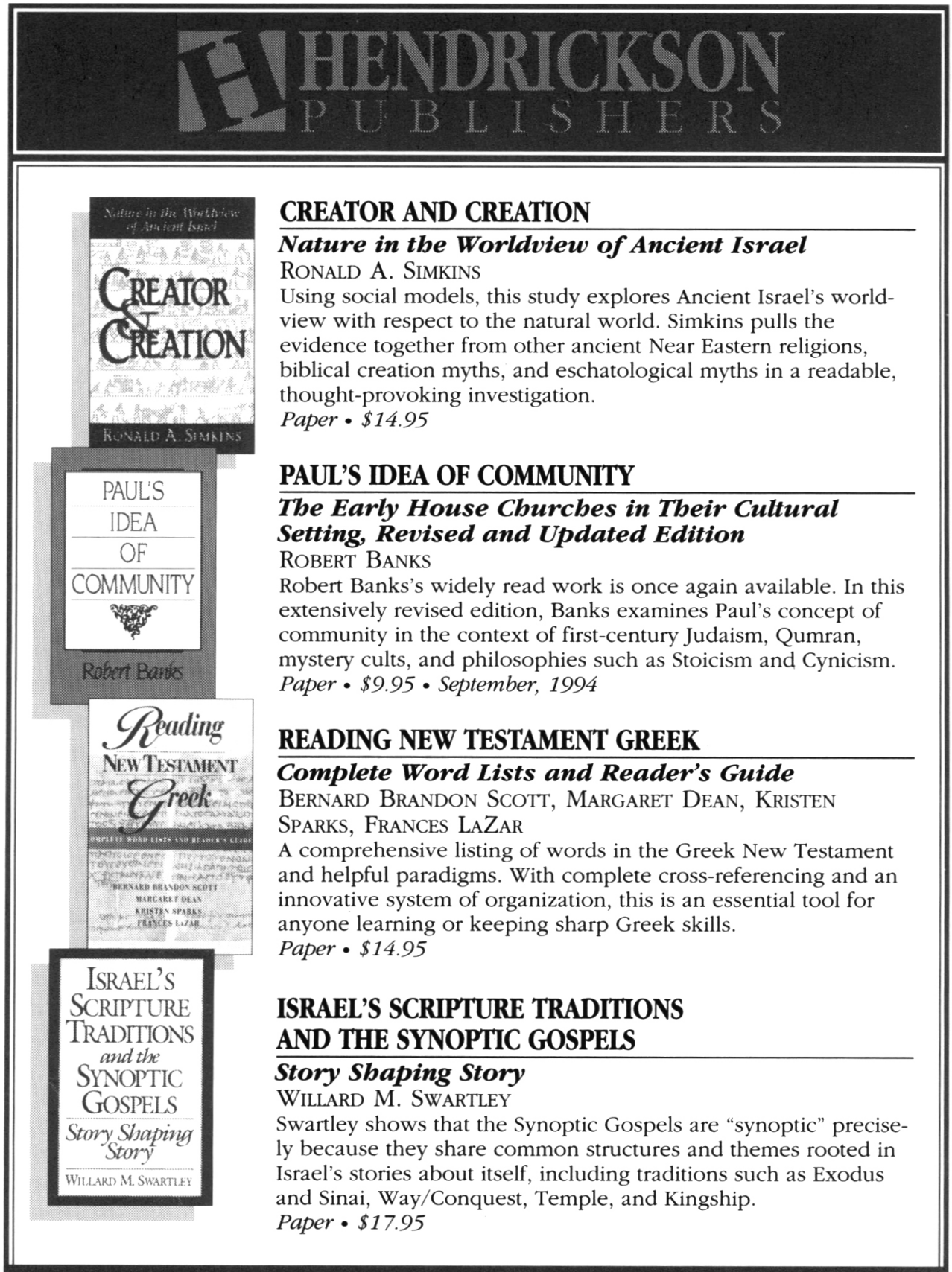

Available at your bookstore, or call toll-free 800-358-3111

Hendrickson Publishers · P.O. Box 3473, Peabody, MA 01961 • 508-532-6546 


\section{Harvard}

\section{Theological}

Studies

\section{MANY ARE CHOSEN Divine Election and Western Nationalisms}

WILLIAM R. HUTCHISON and HARTMUT LEHMANN, Editors

Contributors explore how religious symbolism, especially the biblical rhetoric of "chosenness," figured in the formation of nine nationalist ideologies: South Africa, Switzerland, France, Germany, Israel, the United States, African Americans, Great Britain and Sweden.

176 pages, $\$ 16.00$ paper, Code 1-7091
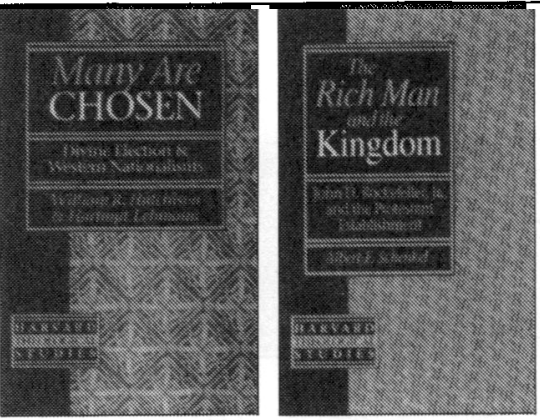

\section{THE RICH MAN AND THE KINGDOM}

John D. Rockefeller Jr. and the Protestant Establishment

ALBERT F. SCHENKEL

Schenkel investigates this century's foremost religious philanthropist, who hoped to use his staggering wealth to fund "a Christian America that could stave civil unrest. In the process he opens a window on the self-understanding of liberal American Protestantism.

192 pages, $\$ 14.00$ paper, Code 1-7092
STANISLAS LUBIENIECKI

HISTORY OF THE

\section{POLISH REFORMATION}

\section{And Nine Related Documents}

Translated and Interpreted by GEORGE HUNTSTON WILLIAMS

Williams here presents the vital data and documents for understanding the religious ferment that overtook Poland in the sixteenth century. Williams has annotated and translated from Latin and Polish ten core documents from the period, chief among them Lubieniecki's History of the Polish Reformation. With 250 illustrations and commentaries. 1008 pages, $\$ 110.00$ cloth, Code $1-7085$

\section{SOMEBODYNESS}

Martin Luther King, Jr., and the Theory of Dignity

GARTH BAKER-FLETCHER

Baker-Fletcher probes King's focal notion of "somebodyness" for a contemporary theory of dignity and for dealing with sexism, denigration of black males, and gang violence.

160 pages, $\$ 12.00$ paper, Code 1-7087

\section{RELIGION AS A PROVINCE}

\section{OF MEANING}

The Kantian Foundations of Modern Theology

ADINA DAVIDOVICH

Davidovich reconfigures Kantian scholarship by demonstrating how the chief lines and import of his work on religion have been misunderstood.

304 pages, $\$ 18.00$ paper, Code 1-7090

\section{THE LEGACY OF}

\section{H. RICHARD NIEBUHR}

RONALD F. THIEMANN, Editor

Essayists in this volume assess Niebuhr's contributions in four areas: confessional identity, theological method, church history, and social ethics.

152 pages, $\$ 15.00$ paper,

Code 1-7084

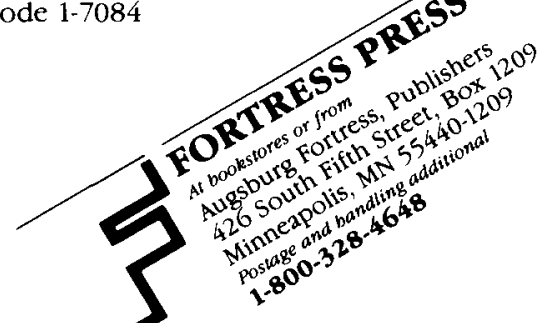




\section{7:3 JULY 1994}

239 Laws of Leviticus 19

Calum M. Carmichael

257 Is Creation Theology Inherently Conservative?

A Dialogue with Walter Brueggemann

J. Richard Middleron

279 Walter Brueggemann's Response

291 The Boundaries of Divine Ontology: The Inclusion and Exclusion of Metatron in the Godhead Daniel Abrams

323 The Punishment of Amalek in Jewish Tradition: Coping with the Moral Problem Avi Sagi

347 The Slavonic Book of Esther: Translation from Hebrew or Evidence for a Lost Greek Text?

Horace G. Lunt and Moshe Tauhe

Notes and Observations

363 "And the Elder Shall Serve the Younger":

A Midrash about Jesus

Ronald N. Brown

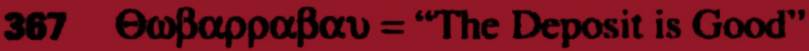
Roy Koransky

371 Books Received 